2016

\title{
Law, Politics, and Legacy Building at the McLachlin Court in 2014
}

Jamie Cameron

Osgoode Hall Law School of York University, jcameron@osgoode.yorku.ca

Follow this and additional works at: http://digitalcommons.osgoode.yorku.ca/olsrps

Part of the Constitutional Law Commons, Judges Commons, and the Law and Politics Commons

\section{Recommended Citation}

Cameron, Jamie, "Law, Politics, and Legacy Building at the McLachlin Court in 2014" (2016). Osgoode Legal Studies Research Paper Series. 140.

http://digitalcommons.osgoode.yorku.ca/olsrps/140 


\title{
OSGOODE HALL LAW SCHOOL \\ LEGAL STUDIES RESEARCH PAPER SERIES
}

Research Paper No. 17

Volume 12, Issue 4, 2016

\section{Law, Politics, and Legacy Building at the McLachlin Court in 2014}

Constitutional Cases 2014, 71 S.C.L.R. (2d) 1- 24, 2015.

\author{
Jamie Cameron
}

This paper can be downloaded free of charge from:

http://ssrn.com/abstract=2714935

Further information and a collection of publications from the Osgoode Hall Law School Legal Studies Research Paper Series can be found at:

http://www.ssrn.com/link/Osgoode-Hall-LEG.html

\section{Editors:}

Editor-in-Chief: Carys J. Craig (Associate Dean of Research \& Institutional Relations and Associate Professor, Osgoode Hall Law School, York University, Toronto)

Production Editor: Kiana Blake (Osgoode Hall Law School, York University, Toronto)

\section{OSGOODE}

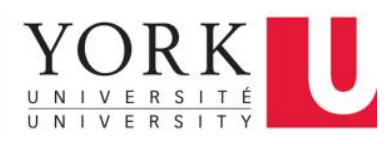


Osgoode Legal Studies Research Paper No. 17

Vol. 12/ Issue. 4/ (2016)

\title{
Law, Politics, and Legacy Building at the McLachlin Court in 2014 Constitutional Cases 2014, 71 S.C.L.R. (2d) 1- 24, 2015.
}

\author{
Jamie Cameron
}

\begin{abstract}
:
This Article was written for Osgoode Hall Law School's annual Constitutional Cases conference, and provides the keynote overview of the McLachlin Court's 2014 constitutional jurisprudence. The Court's 2014 constitutional decisions (Appointment and Senate References; Tsilqot'in Nation; Trial Lawyers) and restrictions on Mr. Big operations (Hart), in combination with a tsunami of Charter decisions early in 2015 (the 2015 Labour Trilogy; Carter v. Canada; R. v. Nur; and others), made this a legacy-building year. More than an overview, this Article probes the nature of the McLachlin Court's legacy this year and the relationship between legal and political dynamics, to ask: in light of Chief Justice McLachlin's modest goals as leader of the Court and the immediate backdrop of the Nadon controversy, the political leadership's attack on the Chief Justice, and poor relations between the institutions, should the jurisprudence of this period be seen as a passive response to events or a more active assertion of judicial authority? Whether this legacymaking jurisprudence was a function of serendipity or opportunity (and perhaps both) is an intriguing question that sheds light on the Chief Justice and her Court in what was a singular and unforgettable year on legal and political measures.

\section{Keywords:}

Supreme Court of Canada, 2014 constitutional decisions \& early 2015 Charter cases, Nadon controversy and attack on the Chief Justice, Chief Justice McLachlin and legacy building in 2014

\section{Author(s):}

Jamie Cameron

Osgoode Hall Law School

E: jcameron@osgoode.yorku.ca
\end{abstract}




\section{Part I}

\section{Annual Review}





\title{
Law, Politics and Legacy Building at the McLachlin Court in 2014
}

\author{
Jamie Cameron ${ }^{*}$
}

\section{WHATEVER HAPPENS, HAPPENS ${ }^{1}$}

From fall 2013, through much of 2014 and almost without respite up to mid-2015, the McLachlin Court and its Chief Justice commanded headlines in the legal and political news of the day. Much of this stemmed from the brouhaha arising from the Nadon appointment, the Appointment Reference and the subsequent political attack on the Chief Justice. $^{2}$ Though the debacle was messy and sensational, 2014 should principally and more appropriately be remembered as a year of legacy making for Chief Justice McLachlin and her Court.

Quantitative numbers suggest a year of business as usual because the volume of cases and success rates for claims fit the general pattern of recent years. ${ }^{3}$ Any peek beyond the data quickly reveals how impressions can mislead. It would be difficult, for instance, to overstate the importance of the two References in spring 2014, and the challenge to the Chief Justice's integrity that ensued. ${ }^{4}$ In the aftermath, the Court continued with pioneering decisions in Tsilhqot'in Nation, recognizing Aboriginal title and Trial Lawyers, protecting access to justice under

* Professor, Osgoode Hall Law School. I thank Kendall Grant (J.D. 2015) and Megan Rourke (J.D. 2017) for providing valuable research assistance, and also thank my colleagues Sonia Lawrence and Benjamin L. Berger for commenting on a draft of the article.

K. Makin, "Ten years as top judge and she's still losing sleep", The Globe and Mail (January 7, 2010) (quoting McLachlin C.J.C.), online: <http:// www.theglobeandmail.com/news/national/ten-years-astop-judge-and-shes-still-losing-sleep/article1366103/>.

Infra, note 4.

See infra, II. Taking the Court's Vitals.

Reference re Supreme Court Act, ss. 5 and 6, [2014] S.C.J. No. 21, [2014] 1 S.C.R. 433 (S.C.C.) [hereinafter "Appointment Reference"]; Reference re Senate Reform, [2014] S.C.J. No. 32, [2014] 1 S.C.R. 704 (S.C.C.) [hereinafter "Senate Reference"]. See generally, L. Sossin, "Court Dismissed: Harper v. McLachlin” The Walrus (January-February 2015), online: $<$ http://thewalrus.ca/ court-dismissed/> (describing and discussing this chain of events). 
section 96 of the Constitution Act, $1867 .^{5}$ Then, early 2015 saw a major correction to 2014's modest gains on rights when the Court issued a series of Charter ${ }^{6}$ decisions, three of which dispatched long-standing precedent without ado. These "precedent busters" further constitutionalized labour relations, granted the right to strike its long-awaited "constitutional benediction," and invalidated Criminal Code ${ }^{7}$ provisions relating to assisted suicide. ${ }^{8}$ Before slowing the pace the Court registered further Charter wins on solicitor-client privilege, religious freedom, mandatory minimum sentences, and minority language rights. ${ }^{9}$ Needless to say, with the McLachlin Court stepping up in this sure-footed way, 2014's unremarkable data are subject to important caveats.

Developments that would be notable at any time are especially remarkable in the 15-year history of the McLachlin Court. Over its tenure, this Court has been thought of and described as pragmatic and even workmanlike. Constitutional rights have been advanced in a careful, selective manner and with limited drama. Review has been contained rather than boisterous; transformative decisions are few in number and have surfaced at intervals. ${ }^{10}$ On the Charter's 30th anniversary, one

5 (U.K.), 30 \& 31 Vict., c. 3. See Tsilhqot'in Nation v. British Columbia, [2014] S.C.J. No. 44, [2014] 2 S.C.R. 257 (S.C.C.) [hereinafter "Tsilhwot' in Nation"]; Trial Lawyers Assn. of British Columbia v. British Columbia (Attorney General), [2014] S.C.J. No. 59, [2014] 3 S.C.R. 31 (S.C.C.) [hereinafter "Trial Lawyers"].

6 Canadian Charter of Rights and Freedoms, Part I of the Constitution Act, 1982, being Schedule B to the Canada Act 1982 (U.K.), 1982, c. 11 [hereinafter "Charter"].

$7 \quad$ R.S.C. 1985 , c. C-46.

8 Mounted Police Assn. of Ontario v. Canada (Attorney General), [2015] S.C.J. No. 1, [2015] 1 S.C.R. 3 (S.C.C.) [hereinafter "Mounted Police"] (collective bargaining); Saskatchewan Federation of Labour v. Saskatchewan, [2015] S.C.J. No. 4, at para. 3, [2015] 1 S.C.R. 245 (S.C.C.) [hereinafter "SFL"] (the right to strike); and Carter v. Canada (Attorney General), [2015] S.C.J. No. 5, [2015] 1 S.C.R. 331 (S.C.C.) [hereinafter "Carter"] (assisted suicide).

Canada (Attorney General) v. Federation of Law Societies of Canada, [2015] S.C.J. No. 7, [2015] 1 S.C.R. 401 (S.C.C.) [hereinafter "Federation of Law Societies"] (solicitor-client privilege); Loyola High School v. Quebec (Attorney General), [2015] S.C.J. No. 12, 2015 SCC 12 (S.C.C.) [hereinafter "Loyola High School"]; Mouvement laïque québécois v. Saguenay (City), [2015] S.C.J. No. 16, 2015 SCC 16 (S.C.C.) [hereinafter "Mouvement laïque Québécois"] (religious freedom); R. v. Nur, [2015] S.C.J. No. 15, 2015 SCC 15 (S.C.C.) (mandatory minimum sentences); and Association des parents de l'école Rose-des-vents v. British Columbia (Education), [2015] S.C.J. No. 21, 2015 SCC 21 (S.C.C.) [hereinafter "Association des parents"] (minority language rights). This article refers only to 2015 Supreme Court decisions up to the end of April; the exception is $R$. $v$. Smith, [2015] S.C.J. No. 34, 2015 SCC 34 (S.C.C.) [hereinafter "Smith"], infra, note 80.

Examples include Dunmore v. Ontario (Attorney General), [2001] S.C.J. No. 87, [2001] 3 S.C.R. 1016 (S.C.C.) (labour relations); Sauvé v. Canada (Chief Electoral Officer), [2002] S.C.J. No. 66, [2002] 3 S.C.R. 519 (S.C.C.) (prisoners' voting rights); Re Vancouver Sun, [2004] S.C.J. No. 41, [2004] 2 S.C.R. 332 (S.C.C.) (open court and investigative hearings under anti-terror legislation); Chaoulli v. Quebec (Attorney General), [2005] S.C.J. No. 33, [2005] 1 S.C.R. 791 (S.C.C.) (access to health care under s. 7); Health Services and Support - Facilities Subsector Bargaining Assn. v. 
commentator remarked that the Charter had become more a "middleground document than an aspirational instrument of progress", and added that " $[t]$ he Court plays a less active role in this iteration, serving more as a yeoman of rights than as a leader in thinking deeply about the Charter's promises and how they can be kept." " A view that may be unkind nonetheless reflects the perception of a Court that — up to this year managed expectations and kept outcomes in check.

Since inception in 2000 and to this day, the McLachlin Court has borne the imprint of the Chief Justice and her style of leadership. By 2014, Beverley McLachlin had been on the Court for 26 years and is now one of its longest-serving members. She is a veteran of the Lamer years, which were punctuated by activist and divisive decisions that generated profound disagreement - in and outside the Court — about the scope of Charter rights and judicial powers. When elevated to the top office in 2000, the Chief Justice quickly indicated her determination to address those negative dynamics. She promised to replace fractured decision-making with collegiality and consensus between the judges, and identified respectful relations between the Court and legislature as another key priority. ${ }^{12}$

British Columbia, [2007] S.C.J. No. 27, [2007] 2 S.C.R. 391 (S.C.C.) (collective bargaining); Canada (Justice) v. Khadr, [2008] S.C.J. No. 28, [2008] 2 S.C.R. 125 (S.C.C.); Canada (Prime Minister) v. Khadr, [2010] S.C.J. No. 3, [2010] 1 S.C.R. 44 (S.C.C.) (constitutional violations related to detention at Guantanamo Bay); Canada (Attorney General) v. PHS Community Services Society, [2011] S.C.J. No. 44, [2011] 3 S.C.R. 134 (S.C.C.) [hereinafter "Insite"] (safe drug injection); and Canada (Attorney General) v. Bedford, [2013] S.C.J. No. 72, [2013] 3 S.C.R. 1101 (S.C.C.) [hereinafter "Bedford"] (Criminal Code provisions related to prostitution).

${ }^{11}$ J. Cameron, "The McLachlin Court and the Charter in 2012" in B.L. Berger, J. Cameron \& S. Lawrence, eds., Constitutional Cases 2012 (2013) 63 S.C.L.R. (2d) 15, at 17. Not only a worthwhile exercise in humility, this quote points out how much and how quickly the Court's fortunes changed, from 2013 - when that was written - to 2014 and early 2015.

12 On consensus, see Janice Tibbetts, "Building Consensus" Canadian Lawyer (July 2013) 24, at 27 (noting that at her first press conference McLachlin C.J.C. identified consensus as one of her goals for the Court). In 2013, the Chief Justice explained how this works, indicating that "all of us, try to eliminate unnecessary concurrences, unnecessary voices, and we talk a lot, we discuss a lot", and that this discussion "leads us often to eliminate some of the differences which have been there". Id., at 28.

On institutional relations, the Chief Justice said, in 2004, that "each branch must discharge its role with integrity and respect for the proper constitutional roles of the other branches": G. Galloway, "Judges Aren't Activists, Chief Justice Says", Globe \& Mail (November 23, 2014) at 11. More recently, she stated that "[t]he courts have to be respectful of Parliament's role and the executive's role", and added that "I think you can see this in our decisions." She continued, commenting that "[w]e're often giving a measure of deference to ministerial decisions" and we often say "and it's not just lip service that Parliament has a right to make these and other choices". In her view, the respect should flow in both directions: "I think the people in government have to treat the courts with respect, otherwise we will undermine our system and it won't work very well." Quoted in J. Brean, “'Conscious Objectivity': That's how the chief justice defines the top court's role. Harper might beg to differ", National Post 
In reflecting on the year it is telling that McLachlin C.J.C. has described her goals, as leader of the Court and as jurist, in humble terms. ${ }^{13}$ She is committed and pragmatic - unhesitant to protect the Constitution at certain junctures, but alive to her intuitive sense of the Court's limited political capital and the need for respectful equilibrium between the branches of government. Chief Justice McLachlin confirmed these sentiments in 2013, warning that she is not one "for shopping lists for the court" and repeating her focus on honest, case-by-case decisionmaking. ${ }^{14}$ She also admitted hoping, simply enough, that the McLachlin Court would be remembered as a "productive, respected court", one that takes each case as it is given and tries to do its best on every one of them. ${ }^{15}$

In personal terms, McLachlin C.J.C. says she has "always wanted to be known as a good jurist, as a serious jurist", and has allowed that she would like to be seen as a "competent jurist" who "did her best to decide the cases that came before her as well as she could and conscientiously". ${ }^{16}$ In describing what this means, the Chief Justice says that she has "always resolved to just try to judge the issues as honestly as [she] can, and not think about things in too strategic a manner". ${ }^{17}$ Her view is that "[m]y job is simply to listen to what the parties have to say, and to do my best to understand the position, the ramifications of deciding one way or the other, to think about what's best for Canadian society ... and give it my best judgment after listening, also, to my eight other colleagues". ${ }^{18}$

The Chief Justice has also commented on the Charter's trajectory, noting in 2010 that the threshold work was completed in the first generation of decision-making, leaving her Court to fine tune and deal "mainly with subtle interpretations". ${ }^{19}$ In her words, "most of the significant Charter of Rights battles" have been fought, and her Court is "just building on that". 20 As far as her tenure as Chief Justice and any legacy are concerned, she was content, at the time, to state in noncommittal terms, that "whatever happens,

(May 23, 2015), online: <http://news.nationalpost.com/news/conscious-objectivity-thats-how-the-chiefjustice-defines-the-top-courts-role-harper-might-beg-to-differ>.

13 In addition to consensus and respectful relations between institutions, access to justice and Supreme Court transparency are other aspirations the Chief Justice has flagged and promoted over the years; see, infra, note 64 .

14 Tibbetts, "Building Consensus", supra, note 12, at 26.

Id., at 26 and 31 .

Quoted in Makin, supra, note 1, and Tibbetts, "Building Consensus", supra, note 12 at 26.

Brean, "Conscious Objectivity", supra, note 12.

Id.

Makin, supra, note 1 .

20 Id. 
happens". ${ }^{21}$ By this she may have meant only to confirm her philosophy that judges are servants of the law and the public office they hold, and discharge their duties as such. Consistent with that, McLachlin C.J.C. maintains that the Court is "totally passive", and has remarked that patterns emerge "only after a serendipitous line of cases" works its way up to the Court. ${ }^{22}$

Against that backdrop, the past year stands in sharp profile: in constitutional and Charter domains, and whether wittingly or not, the Court generated a legacy-setting jurisprudence. True enough, the federal government was spoiling for a fight with the Court in recent years, at times forcing the judges to choose between deference to its policies and enforcing the Charter's promises. The Court and public had fair warning that the government intended to implement criminal justice policies that could not easily be squared with the Charter. In addition, "skirmish" decisions foreshadowed the prospect of deeper conflict between the institutions. $^{23}$ There was a certain sense of the Court being pushed to allow transgressions or defend the Constitution. This climate preceded the political leadership's rash and astonishing attack on the Chief Justice, which was the most extraordinary event of 2014, if not the Court's entire institutional history.

Setting the political dynamics aside for the moment, the Court's constitutional jurisprudence in this period is striking, because it far outstrips the modest goals the Chief Justice has earnestly and valiantly proclaimed over the years. Rather than be deterred or intimidated, the Court steeled its resolve when the federal government placed the judges in the awkward position of confronting the Prime Minister and declaring that the appointment of a colleague - already sworn in - was illegal. In the Appointment Reference, the Court defended its institutional integrity, sent the Prime Minister's appointee away, and constitutionalized Supreme Court appointments. Then, it challenged the federal government's assertion of parliamentary hegemony to amend the Senate, and protected the upper house's position in Canada's scheme of federalism. After the fallout from the References settled, the Court pressed on with a series of decisions enforcing constitutional rights across a range of high profile issues.

\footnotetext{
$21 \quad$ Id

22 Brean, "Conscious Objectivity", supra, note 12, and Makin, supra, note 1 (in reference to press freedoms and free expression but noting, as well, that "[i]t wasn't that we planned it that way, but people brought the cases forward, they were good cases, and the law developed as it did"; $i d$.).

23. See the Khadr decisions, Insite and Bedford, supra, note 10.
} 
Throughout, the Court showed poise as a whole, rising above the fray to demonstrate solidarity, fortitude, and confidence in its mandate of review. In doing so, the judges may have drawn on an existing sense of institutional self-sufficiency, but maybe the Court also saw and felt its own vulnerability to the exercise of executive power. By advancing, rather than retreating after the appointment debacle, the Court galvanized its place in Canadian democracy and public life. In that process, the McLachlin Court embedded important precedent in the constitutional jurisprudence. That narrative presents an interface between law and politics that raises searching questions about the identity of the McLachlin Court, and its response to the rare institutional pressures of the past year.

As is customary, this review provides a quantitative survey of the Supreme Court's 2014 constitutional cases and, for the reasons noted, incorporates the Court's early 2015 jurisprudence. After doing so, the discussion returns in a brief and final section to the Chief Justice, the McLachlin Court and the legacy that was forged in a year of unforgettable and singular institutional dynamics.

\section{TAKING THE COURT’S VITALS}

Critical review of the Supreme Court's constitutional cases is the mandate of the annual conference. ${ }^{24}$ Quantitative analysis of the year's jurisprudence is a key part of that review, and has been a feature of the program from the outset. ${ }^{25}$ Though the case sample may be small, the Court's constitutional numbers provide valuable information and offer a platform for exploring themes. ${ }^{26}$ But what the data reveal is limited and must be accompanied by commentary that provides qualitative insight and perspective. ${ }^{27}$

24 This year's conference, "The 2014 Constitutional Cases Conference: The 18th Annual Analysis of the Constitutional Decisions of the Supreme Court of Canada", was held on April 10, 2015. The conference opens with a keynote overview of the Court's constitutional jurisprudence, and I thank my colleagues Professors Benjamin L. Berger and Sonia Lawrence for inviting me to give that address.

25 For another review which selects the Court's top 10 decisions and discusses its work from October 31, 2013 to November 30, 2014, see B. Perrin, "The Supreme Court of Canada: Policy-Maker of the Year", MacDonald-Laurier Institute, November 2014, online: <http://www.macdonaldlaurier.ca/ files/pdf/MLI_SupremeCourt_NewFinal_web_r2.pdf $>$.

26 The annual review articles dating back to 2000, when Beverley McLachlin was appointed Chief Justice, can be found at York Digital Journals, online: $<$ http://sclr.journals.yorku.ca/index.php/sclr>.

${ }^{27}$ At the conference, leading constitutional scholars and experts provided deeper analysis on the jurisprudence and broader themes, in panels on Indigenous peoples and the Constitution; the Constitution Act, 1867; prisons and punishment; fundamental freedoms; Mr. Big and developments 
The starting point is the Supreme Court's output in the calendar year. The SCC website reports 79 decisions in 2014, of which 18 - or about 22 per cent - are anchored in the Constitution. ${ }^{28}$ It is reassuring to note that the numbers and percentages square generally with the pattern of recent years. ${ }^{29}$ As well, by claiming 12 of 18 - a two-thirds share of the total - the Charter once again dominated the jurisprudence. At 16 per cent, the 2014 success rate on Charter claims aligns with outcomes in the last five years: 15 per cent in 2013; 20 per cent in 2012; 18 per cent in 2011; and 18 per cent in $20100^{30}$ Though a rate in the $15-20$ per cent range is stable, it is easy to forget that Charter claims attained a success rate, on average, of 45 per cent per year in the first 10 years of the McLachlin Court. ${ }^{31}$

The Court's output on rights in 2014 disappoints because it failed to yield a landmark that notably advanced or affected the Charter's interpretation. ${ }^{32}$ Criminal justice accounts for nine of 12 cases and 11 arose under the Charter's legal rights, leaving one orphan under section $2(\mathrm{~d}) .^{33}$

in police powers; and constitutional justice in the "longue durée". Their papers are published in this volume of the Supreme Court Law Review.

$28<$ https://scc-csc.lexum.com/scc-csc/scc-csc/en/2014/nav_date.do $>$.

29 In 2013, 11 of 74 cases, or about 15 per cent, were constitutional cases; in 2012, the number was 11 of 75 , and also about 15 per cent; and in 2011, the number was 19 out of 75 , or about 20 per cent of the annual jurisprudence. The year 2010 stands out, because 25 of the Court's 67 decisions, or about 37 per cent, addressed constitutional issues. See generally, J. Cameron, "The McLachlin Court and the Charter in 2012", supra, note 11, at 20-23 (discussing the data over the years); and S. Lawrence, "2013: Constitutional Cases in Review" in J. Cameron, B.L. Berger \& S. Lawrence, eds., Constitutional Cases 2013 (2014) 67 S.C.L.R. (2d) 1, at 3-4 (providing 2013 data).

30 Cameron, $i d$., at 20-21.

31 Cameron, id., at 20 (citing P. Monahan \& J. Yap, "Constitutional Cases 2009: An Overview", in J. Cameron \& B. Ryder, eds., Constitutional Cases 2009, (2010) 51 S.C.L.R. (2d) 3, at 3).

32 But see Spencer, infra, note 33 (finding a reasonable expectation of privacy in Internet subscriber information); Fearon, infra, note 33 (addressing cell phone privacy rights); see also Hart, infra, note 46 (non-Charter decision placing restrictions on "Mr. Big" police operations). For comment in this volume, see N. Hasan, "A Step Forward or Just a Sidestep? Year Five of the Supreme Court of Canada in the Digital Age"; and S. Magotiaux, "Out of Sync: Section 8 and Technological Advancement in Supreme Court Jurisprudence".

33 The criminal cases are: R. v. MacDonald, [2014] S.C.J. No. 3, [2014] 1 S.C.R. 37 (S.C.C.) [hereinafter "MacDonald"]; R. v. Babos, [2014] S.C.J. No. 16, [2014] 1 S.C.R. 309 (S.C.C.) [hereinafter "Babos"]; Canada (Attorney General) v. Whaling, [2014] S.C.J. No. 20, [2014] 1 S.C.R. 392 (S.C.C.) [hereinafter "Whaling"]; R. v. Mian, [2014] S.C.J. No. 54, [2014] 2 S.C.R. 689 (S.C.C.) [hereinafter "Mian"]; R. v. Anderson, [2014] S.C.J. No. 41, [2014] 2 S.C.R. 167 (S.C.C.) [hereinafter “Anderson"]; $R$. v. Spencer, [2014] S.C.J. No. 43, [2014] 2 S.C.R. 212 (S.C.C.) [hereinafter "Spencer"] R. v. Conception, [2014] S.C.J. No. 60, [2014] 3 S.C.R. 82 (S.C.C.) [hereinafter "Conception"]; Wakeling v. United States of America, [2014] S.C.J. No. 72, [2014] 3 S.C.R. 549 (S.C.C.) [hereinafter "Wakeling"] and R. v. Fearon, [2014] S.C.J. No. 77, [2014] 3 S.C.R. 621 (S.C.C.) [hereinafter "Fearon"].

The two non-criminal legal rights cases are Canada (Citizenship and Immigration) v. Harkat, [2014] S.C.J. No. 37, [2014] 2 S.C.R. 33 (S.C.C.) [hereinafter "Harkat"] (s. 7); and Kazemi Estate v. Islamic Republic of Iran, [2014] S.C.J. No. 62, [2014] 3 S.C.R. 176 (S.C.C.) [hereinafter "Kazemi Estate"] (s. 7). 
Though the claim prevailed twice, under sections 11(h) and 10(h), neither success was weighty. While Whaling invalidated part of the government's get-tough policy on sentencing, the retrospective alteration of parole entitlements did not require interpretive finesse, and Mian found a section 10(b) violation but was more concerned with the scope of appellate review. ${ }^{34}$ Other claims either failed or acknowledged the Charter violation without excluding illegally obtained evidence. ${ }^{35}$

The prevalence of legal rights obscured other entitlements that played little or no role in the 2014 jurisprudence. The demoralization of section 15 has been lamented for some time, and the equality guarantee again failed to generate a precedent. ${ }^{36} \mathrm{~A}$ further concern is that section $2(\mathrm{~b})$ which was also absent in 2014 - might be about to join section 15 in decline. ${ }^{37}$ If the Charter's first 30 years attest that lulls in jurisprudential activity can be expected, it is worth remembering that these guarantees had enormous vitality in the formative years. Despite maintaining a healthy presence on the docket for some time, equality and expressive freedom have become less relevant in the current jurisprudence. Though section 15's status has been noted and discussed with concern, section 2(b)'s low profile has not attracted much attention. Given the pattern, it may not be premature to ask whether the jurisprudence is trending in a way that reflects core perceptions about the Charter's long-term mandate, or more accurately represents a passing dynamic grounded in a political focus on criminal justice, and the judiciary's response to that priority. The question, in other words, is whether the Court is as passive as the Chief Justice suggested, or has played a role in placing these guarantees in the background. ${ }^{38}$

Bernard v. Canada (Attorney General), [2014] S.C.J. No. 13, [2014] 1 S.C.R. 227 (S.C.C.) [hereinafter "Bernard"], was the only case in 2014 that fell outside ss. 7-14 of the Charter.

34 See H. Stewart, "Punitive in Effect: Reflections on Canada v. Whaling" (in this volume).

35 Spencer and Fearon, supra, note 33 (not excluding evidence obtained in violation of s. 8).

36 Though argued in the courts below, the s. 15 claim in Anderson, supra, note 33, was abandoned at the Supreme Court of Canada; see also Carter, supra, note 8, at para. 93 (declining to address s. 15 issues that received full attention in the courts below).

${ }^{37}$ Section 2(b) failed to generate a decision in 2014; before then the claim succeeded once in Alberta (Information and Privacy Commissioner) v. United Food and Commercial Workers, Local 401, [2013] S.C.J. No. 62, [2013] 3 S.C.R. 733 (S.C.C.) (protecting picket line expressive activity) and otherwise substantially failed in Saskatchewan (Human Rights Commission) v. Whatcott, [2013] S.C.J. No. 11, [2013] 1 S.C.R. 467 (S.C.C.) (upholding limits on anti-gay expressive activity) and R. v. Khawaja, [2012] S.C.J. No. 69, [2012] 3 S.C.R. 555 (S.C.C.) (rejecting s. 2 challenges to the definition of "terrorist activity"). See also B. (A.) v. Bragg Communications, Inc., [2012] S.C.J. No. 46, [2012] 2 S.C.R. 567 (S.C.C.) (anonymizing the plaintiff's name and denying the request for a publication ban).

38 An answer requires more rigorous investigation. Still, it is worth noting that the Court recently refused leave to appeal in two notable cases under ss. 2 and 15: McAteer v. Canada (Attorney General), [2014] O.J. No. 3728, 2014 ONCA 578 (Ont. C.A.), leave to appeal refused [2014] S.C.C.A. 
If the Charter jurisprudence is modest, what sets the 2014 constitutional calendar apart are the Court's non-Charter cases. Six decisions on federalism, national institutions and Aboriginal rights accounted for about 31 per cent of the Court's constitutional decisionmaking. ${ }^{39}$ The Supreme Court's Reference decisions on Supreme Court appointments and Senate reform addressed the constitutional status of national institutions and provided critical guidance on the requirements of constitutional change. ${ }^{40}$ Then Tsilhqot'in Nation's altered the law on Aboriginal title and proactively created a framework to regulate land use. ${ }^{41}$ Almost any attempt to capture the significance of these decisions and the Court's profile in the early months of 2014 would be inadequate. Later in the year, Trial Lawyers marked another significant departure when the Court deployed the division of powers to constitutionalize access to justice. ${ }^{42}$ Though less newsworthy, the Court's decision to limit provincial jurisdiction by embedding that entitlement in section 96 of the Constitution Act, 1867 - in reliance on unwritten constitutional principles — was a major decision, doctrinally and jurisprudentially. ${ }^{43}$ Grassy Narrows was a second Aboriginal decision in

No. 444 (S.C.C.) (s. 2 challenge to the citizenship oath to the Queen); and Tanudjaja v. Canada (Attorney General), [2014] O.J. No. 5689, 2014 ONCA 852 (Ont. C.A.), leave to appeal refused [2015] S.C.C.A. No. 39 (S.C.C.) (economic rights for homeless persons under ss. 7 and 15).

39 Non-Charter cases fluctuate from year to year and are not usually a defining feature of the annual docket: for instance, there was one Aboriginal and one federalism case in 2013; one division of powers decision in 2012; and two division of powers and one Aboriginal decision in 2011. In 2010 there were four division of powers decisions and three on Aboriginal issues.

In 2014, see the Appointment Reference, supra, note 4; the Senate Reference, supra, note 4; Tsilhqot'in Nation, supra, note 5; Grassy Narrows First Nation v. Ontario (Natural Resources), [2014] S.C.J. No. 48, [2014] 2 S.C.R. 447 (S.C.C.) [hereinafter "Grassy Narrows"]; Bank of Montreal v. Marcotte, [2014] S.C.J. No. 55, [2014] 2 S.C.R. 725 (S.C.C.) [hereinafter "Marcotte"]; and Trial Lawyers, supra, note 5.

${ }_{40} \quad$ In this volume see R. Haigh, "You Don't Need a Metaphor to Know Which Way the Case Goes: The Senate Reference and Constitutional Metaphors"; C. Mathen, "The Shadow of Absurdity and the Challenge of Easy Cases: Looking Back on the Supreme Court Act Reference".

${ }^{41}$ See A. Boisselle, "To Dignity Through the Backdoor: Tsilhqot'in and the "Aboriginal Title' Test"; J. Borrows, "Aboriginal Title and Private Property"; K. McNeil, "Aboriginal Title and the Provinces After Tsilhqot'in Nation"; and B. Slattery, "The Constitutional Dimensions of Aboriginal Title" (all this volume).

42 Trial Lawyers relied on the division of powers and unwritten principles - the rule of law to invalidate hearing fees under s. 96 because they infringe the core jurisdiction of the courts by denying individuals access to justice. Chief Justice McLachlin held that "[a]s access to justice is fundamental to the rule of law, and the rule of law is fostered by the continued existence of the s. 96 courts, it is only natural that s. 96 provide some degree of protection for access to justice". Trial Lawyers, supra, note 5, at para. 39.

43 See Rothstein J. (arguing, in dissent, that "[i]n using an unwritten principle to support expanding the ambit of s. 96 to such an extent, the majority subverts the structure of the Constitution and jeopardizes the primacy of the written text"); id., at para. 93 . 
which the claim failed, and a trio of banking cases from Quebec - in which the claim also failed - rounded out 2014's constitutional decisions. ${ }^{44}$

Overall, a quantitative survey of 2014 confirms that while the Court was active on constitutional issues, the Charter essentially marked time. As noted, the numbers provide little indication that 2014 was a year quite unlike any other. Yet the institutional decisions on the Supreme Court and Senate were not just constitutionally dramatic but politically seismic as well. The springtime Reference decisions dealt the federal government setbacks that triggered a shocking and unprecedented political attack on the Chief Justice and her Court. On May 1, 2014, the Prime Minister and Minister of Justice publicly impugned McLachlin C.J.C.'s integrity in a way that was almost universally dismissed as shabby, unwarranted and unstatesmanlike. ${ }^{45}$ The attack had profound consequences for the Court and government, and a public unaccustomed to such a lack of courtesy in institutional dealings.

It is also necessary, methodologically, to contextualize the quantitative survey in other ways. First, a straight tally treats decisions of wildly varying significance as equals; though each counts as one, it is obvious to all that the Court's 2014 constitutional decisions handily eclipsed its developments under the Charter. Additionally, a formal count also excludes "near" constitutional cases, which address doctrinal protections that are not formally decided under the Charter. ${ }^{46}$ Imperative in any review of the 2014 jurisprudence is $R$. v. Hart and the restrictions the Court placed on "Mr. Big" operations. Though assigned, in doctrinal terms, to the common law of confessions, Hart implicates the right to silence and freedom from

44 The Quebec trilogy on banking counts as one decision, in this survey, because Marcotte provided the key discussion on the constitutional issue. See also Amex Bank of Canada v. Adams, [2014] S.C.J. No. 56, [2014] 2 S.C.R. 787 (S.C.C.); Marcotte v. Fédération des caisses Desjardins du Québec, [2014] S.C.J. No. 57, [2014] 2 S.C.R. 805 (S.C.C.). For a comment in this volume see W. Wright, "Of Banks, Federalism and Clear Statement Rules: Bank of Montreal v. Marcotte".

45 There is an enormous online commentary on all aspects of the Nadon appointment; see generally, Sossin, "Court Dismissed", supra, note 4.

46 While surveys in the past may have included decisions on Charter values and common law "rights", the 2014 overview does not. Decisions of note include R. v. Hart, [2014] S.C.J. No. 52, [2014] 2 S.C.R. 544 (S.C.C.) [hereinafter "Hart"] and R. v. Mack, [2014] S.C.J. No. 58, [2014] 3 S.C.R. 3 (S.C.C.) [hereinafter "Mack"] ("Mr. Big" operations, confessions, and self incrimination); R. v. Clarke, [2014] S.C.J. No. 100, [2014] 1 S.C.R. 612 (S.C.C.) (Charter values argued but not engaged); R. v. Quesnelle, [2014] S.C.J. No. 46, [2014] 2 S.C.R. 390 (S.C.C.) (Mills and Criminal Code disclosure regimes); Mission Institution v. Khela, [2014] S.C.J. No. 24, [2014] 1 S.C.R. 502 (S.C.C.) (habeas corpus and procedural fairness in a prison setting); and $R$. $v$. Summers, [2014] S.C.J. No. 26, [2014] 1 S.C.R. 575 (S.C.C.) (reading provisions in the Truth in Sentencing Act, S.C. 2009, c. 29 against principles of sentencing). 
self-incrimination under section 7 , as attested by a concurring opinion, which would have anchored limits on these tactics in the Charter. ${ }^{47}$

Finally, the Court's tsunami of Charter decisions in early 2015 pointed up another limit of the calendar approach. In the period from January 1 to the Charter's anniversary on April 17, 2015, the Court released 15 decisions, of which eight - or more than 50 per cent arose under the Constitution. ${ }^{48}$ During this whirlwind, the Charter claim succeeded in six instances, or about 85 per cent of the cases, and lost only once. Though decision-making has settled, the pattern continued with the release of other significant decisions in spring $2015 .^{49}$

The 2014 overview should not overreach its mandate, but nor can it ignore the extraordinary flow of constitutional decisions early in 2015 . That flow especially points up the folly of surveying a jurisprudence that simply is not oriented to the calendar year. Showcasing or overvaluing annual numbers is somewhat arbitrary and can encourage misleading or inaccurate impressions. The Court's decision-making is seamless, and a meaningful commentary must acknowledge its burst of Charter decisions at the outset of 2015 . Doing so shows quite clearly that, far from being a disappointment, the Charter jurisprudence arising from the 2014 docket was strong and in some instances even transformative.

From any perspective, 2015's early returns are remarkable. With an ongoing exception for section 2(b), the Court restored section 2's freedoms (of religion and association) to a place of stature in the

47 Justice Karakatsanis, concurring. On any view, Hart, id., is a landmark, despite differences of opinion about whether it should have been decided under the Charter or the law of confessions. For comments in this volume, see S. Coughlan, "Threading Together Abuse of Process and Exclusion of Evidence: How it Became Possible to Rebuke Mr. Big"; L. Dufraimont, "Hart and Mack: New Restraints on Mr. Big and a New Approach to Unreliable Prosecution Evidence".

${ }_{48}$ The Court decided seven Charter cases between January 1 and the anniversary of the Charter on April 17, 2015; the claim only failed once, in Meredith v. Canada (Attorney General), and the eighth decision concerned the status of the federal Gun Registry and whether Quebec was constitutionally entitled to have access to the registry information. See Mounted Police, supra, note 8; Meredith v. Canada (Attorney General), [2015] S.C.J. No. 2, [2015] 1 S.C.R. 125 (S.C.C.) [hereinafter "Meredith"]; and SFL, supra, note 8 ("the 2015 Labour Trilogy"); Carter, supra, note 8 (assisted suicide under s. 7); Federation of Law Societies of Canada, supra, note 9 (s. 7); Loyola High School, supra, note 9 (s. 2(a)); and Nur, supra, note 9 (s. 12). See also Quebec (Attorney General) v. Canada (Attorney General), [2015] S.C.J. No. 14, 2015 SCC 14 (S.C.C.) (constitutional access to the Gun Registry database) [hereinafter "Gun Registry case"].

${ }_{49} \quad$ To the end of April, see also Mouvement laïque québécois, supra, note 9 (municipal prayer and human rights legislation); and Association des parents, supra, note 9 (minority language rights). 
jurisprudence, invalidated Criminal Code provisions, challenged the current government's criminal justice policy, and reactivated minority language rights. Three of the Court's landmarks in this period - namely, Mounted Police, SFL and Carter - blasted long-standing authority on labour relations and prohibitions on assisted suicide. Early in January, the Court overruled precedent to grant Mounted Police the constitutional right to engage in meaningful collective bargaining. ${ }^{50}$ Within weeks, the Court overruled precedent of 28 years' standing and proclaimed a constitutional benediction for the right to strike in SFL. ${ }^{51}$ Finally, the full Court unanimously invalidated sections 14 and 241 of the Criminal Code only a few months after hearing the appeal. ${ }^{52}$ Unlike the labour cases, Carter v. Canada purported not to overrule Rodriguez v. British Columbia, and did so in unattributed or anonymous reasons by "the Court". ${ }^{53}$ Not to be overlooked in this mix are further decisions protecting solicitor-client privilege under section 7, exempting a denominational school from provincial curriculum requirements, invalidating a mandatory minimum for firearms offences, and finding that municipal prayer violates human rights legislation. ${ }^{54}$ Separately and in combination, inspired decision-making brought fresh energy to the Court's interpretation of the Charter.

It is difficult to recall another period when the McLachlin Court asserted itself in this way, with strong and confident decisions across a range of issues. Justice LeBel's retirement and looming departure from the Court was a factor in the "hurry up" manner of 2015 decisionmaking, but does not fully explain the enormity - and even the air of urgency - of what court watchers witnessed at the beginning of the year.

$50 \quad$ Supra, note 8 (overruling Delisle v. Canada (Attorney General), [1999] S.C.J. No. 43, [1999] 2 S.C.R. 989 (S.C.C.) and "explaining" Ontario (Attorney General) v. Fraser, [2011] S.C.J. No. 20, [2011] 2 S.C.R. 3 (S.C.C.) [hereinafter "Fraser"]).

51 SFL, supra, note 8, at para. 3 (overruling Reference re Public Service Employee Relations Act (Alberta), [1987] S.C.J. No. 10, [1987] 1 S.C.R. 313 (S.C.C.)). In this volume, see M. Dunn, "Many Questions and a Few Answers: Freedom of Association after Saskatchewan Federation of Labour, Mounted Police, and Meredith".

52 The appeal was heard on October 15, 2014 and decided with alacrity on February 6, 2015.

53 Unlike Mounted Police and SFL, which explicitly overruled precedent to the contrary, Carter "distinguished" Rodriguez v. British Columbia (Attorney General), [1993] S.C.J. No. 94, [1993] 3 S.C.R. 519 (S.C.C.) [hereinafter "Rodriguez"] (upholding the same Criminal Code provision).

$54 \quad$ Federation of Law Societies, Loyola High School and Nur, supra, note 9. For a comment on Loyola High School in this volume, see H. Kislowicz, "Loyola High School v. Attorney General of Quebec: On Non-triviality and the Charter Value of Religious Freedom". 


\section{The Supreme COURT CAST}

A scan of authorship in Supreme Court decision-making demonstrates, albeit with some judges more active than others, that writing assignments were well distributed. Before turning to the judges themselves, preliminary observations can be made. The first is that, in practical terms, the McLachlin Court was profoundly affected by the prolonged controversy surrounding Justice Nadon's appointment. ${ }^{55}$ The Court was short-staffed and unable to sit as a panel of nine from October 2013 to June 2014, with the result that only one case was decided by all members of the Court. By early 2015, a full Court participated in three of the Court's eight Charter decisions, with the balance in this period decided by seven or eight-member panels. ${ }^{56}$

A second preliminary observation is that unanimity is often considered an important sign of the Court's collegiality, solidarity, and functioning. In 2014, 10 of its 18 constitutional decisions, or about 55 per cent, were unanimous on outcome and were accompanied, in two instances, by concurring reasons. ${ }^{57}$ Meanwhile, at close to 45 per cent, the incidence of dissent provided a visible and healthy sign of disagreement among the judges on difficult issues. ${ }^{58}$ The only unanimous

55 Justice Fish retired on August 31, 2013, and was replaced by Nadon J., whose appointment was announced on September 30, 2013. Despite being sworn in on October 7, 2013, Nadon J. never sat as a member of the Supreme Court of Canada, and was barred from the Supreme Court building once his appointment was challenged and the federal government stated reference questions to the Court. Justice Fish's place at the Court was vacant, as a result, for almost a year from August 2013 to June 12, 2014 - when Gascon J. was appointed to the Court. The Court's website has removed any and all references to Nadon J.

56 Of the cases decided in the 2014 calendar year, only $R$. v. Conception was heard by nine judges, and that is because it was "re-heard" after Gascon J. was appointed. In early 2015, Carter, the Gun Registry case and Nur were heard and decided by the full Court. In 2014, the Senate Reference, Tsilhqot'in Nation, Whaling, Harkat and Spencer were heard by a panel of eight judges, and the balance of the constitutional decisions were heard by a panel of seven judges; in 2015, the 2015 Labour Trilogy, Federation of Law Societies, and Loyola High School were decided by sevenmember panels.

57 The unanimous decisions are the Senate Reference, Bank of Montreal v. Marcotte, Tsilhqot'in Nation, Grassy Narrows, Whaling, Anderson, Spencer and Mian; concurring reasons accompanied the majority opinion in Conception and MacDonald. There were concurring and dissenting reasons in Trial Lawyers and Wakeling.

58 For dissenting reasons see the Appointment Reference (per Moldaver J.); Trial Lawyers (per Rothstein J.); Bernard (partial dissent) (per Rothstein J., Moldaver J. concurring); Babos (per Abella J.); Harkat (per Abella and Cromwell JJ.); Kazemi Estate (per Abella J.); Wakeling (per Karakatsanis J., Abella and Cromwell JJ., concurring); and Fearon (per Karakatsanis J., LeBel and Abella JJ., concurring). The Court divided 4-3 in Wakeling and Fearon; Justice Abella dissented alone in Babos and Kazemi Estate; Rothstein J.'s sole dissent was Trial Lawyers and Moldaver J.'s was the Appointment Reference. 
opinion in early 2015 was Carter v. Canada, though the Court's majority opinions in Federation of Law Societies, Loyola High School and Mouvement laïque québécois were supplemented by concurring reasons. Notably, four of the Court's eight cases up to the Charter's 2015 anniversary - or 50 per cent - yielded pointed dissenting opinions in the three section 2(d) labour relations cases, as well as in the Gun Registry case, which was decided by a 5-4 margin, before Nur again divided the Court by a vote of 6-3.

A third observation concerns the Court's anonymous reasons in both References and Carter. The Senate Reference was unanimous but the Appointment Reference was not, and though there is precedent for it, still it is unusual for the Court to anonymize majority reasons when the panel is not unanimous. ${ }^{59}$ In addition, the full Court's decision on assisted suicide in Carter was also anonymous. It is often thought that the Court elects to speak anonymously, and as one, on issues of institutional delicacy; classic examples include the Patriation and Secession References. ${ }^{60}$ Even so it is puzzling that anonymous reasons by "the Court" attract so little attention and the practice is accepted virtually without comment. ${ }^{61}$ Though it could be argued that a decision by "the Court" is appropriate for so-called "advisory opinions", it is not selfevident that the same rationale applies to ordinary appeals. Nor does the controversy associated with particular decisions explain why some decisions, but not others, are singled out for institutional authorship. ${ }^{62}$ Solidarity for solidarity's sake is not a convincing rationale in a case like Carter. ${ }^{63}$ Though unanimity might boost the legitimacy, credibility and authority of a decision, it is not clear the same applies to anonymous

59 See, e.g., Re Resolution to amend the Constitution, [1981] S.C.J. No. 58, [1981] 1 S.C.R. 753 (S.C.C.) [hereinafter "Patriation Reference"] (majority and minority reasons on the legal and constitutional issues which listed the judges concurring in each opinion but not the author); Irwin Toy Ltd. v. Quebec (Attorney General), [1989] 1 S.C.R. 927 (reasons by "the Court" represented a majority of three on a panel of five judges deciding the case).

60 The Patriation Reference, id.; Reference re Secession of Quebec, [1998] S.C.J. No. 61, [1998] 2 S.C.R. 217 (S.C.C.) [hereinafter "Secession Reference"].

But see P. McCormick \& M. Zanoni, "The First 'By the Court' Decisions: The Emergence of a Practice at the Supreme Court of Canada" (forthcoming, Manitoba Law Journal; draft on file with the author). Professor McCormick advises that he has a book on topic, to be published by University of Toronto Press.

62 Compare Bedford and Insite, (both authored by the Chief Justice) and the Court's two decisions in Khadr (authored by "the Court"); supra, note 10.

63 The Court's decision in Carter was particularly lacking in decision-making transparency: not only did the judges fail to identify the opinion's author or authors, it claimed — without credibility - that Carter did not overrule Rodriguez, supra, note 53, in which then Justice McLachlin wrote a prominent dissenting opinion. 
decision writing. The Court's reasons for decision are one of the few sources of transparency and accountability in its work, and the authors of decisions that become the supreme law of the land should be disclosed, not withheld. ${ }^{64}$ At the least, the practice and purpose of anonymous decision-making at the Supreme Court should be placed under closer analytical scrutiny.

Also noteworthy over the years is the McLachlin Court's regularization and institutionalization of teamwork in the form of joint opinions. ${ }^{65}$ Shared responsibility for reasons has become an accepted practice at the Court, as the following writing teams in this period demonstrate: McLachlin-LeBel and McLachlin-Moldaver; Abella-Cromwell; RothsteinMoldaver, Rothstein-Wagner and Rothstein-Cromwell; Moldaver-Wagner; and Cromwell-Karakatsanis. ${ }^{66}$ The most notable instance of joint authorship may be the Gun Registry case, where the three judges from Quebec dissented jointly and in unison from the majority opinion rejecting the province's claim of constitutional access to the long gun registry database. ${ }^{67}$ Otherwise, pairings that were frequent and at times unexpected - such as the two joint concurrences by the Chief Justice and Moldaver J. - may have enabled the judges to manage the workload for an extended period when the Court was not at full complement.

The Chief Justice wrote five times in constitutional cases decided in 2014: twice the Court was unanimous; twice she held a majority; and once she wrote a sole concurrence. ${ }^{68}$ She also joined Justice Karakatsanis's concurrence in Conception, but neither wrote nor participated in a dissent in this period. To her 2014 landmarks in Tsilhqot'in Nation and Trial Lawyers, the Chief Justice added Mounted Police and Nur early in 2015. In doing so, she continued her practice of

64 The Court's commitment to public access to its processes and hearings is commendable. The many resources that are available can be found at the Supreme Court of Canada website: $<$ http://www.scc-csc.gc.ca/>.

${ }_{65}$ See P. McCormick, "Sharing the Spotlight: Co-authored Reasons on the Modern Supreme Court of Canada" (2011) 34 Dal. L.J. 165.

${ }_{66}$ The Chief Justice wrote joint reasons with LeBel J. in Mounted Police and Meredith, and with Moldaver J. in Law Societies and Loyola. Justice Cromwell wrote a joint dissent with Abella J. in Harkat, a joint majority opinion with Rothstein J. in Conception, and a joint majority opinion with Karakatsanis J. in the Gun Registry case; Justice Rothstein additionally teamed up with Moldaver J. in partial dissent in Bernard, and with Wagner J. in dissent in SFL; and Justices Moldaver and Wagner co-wrote the majority opinion in MacDonald.

${ }_{67}$ Justice Abella joined the dissent, which resulted in a 5-4 division on the Court.

68 Her unanimous decisions were Tsilhqot'in Nation and Grassy Narrows; her majority opinions were Harkat and Trial Lawyers; and her sole concurrence was Wakeling. 
co-writing with LeBel J. in two of the Court's 2015 labour relations decisions. ${ }^{69}$

With all puisne judges playing an active role in decision-making, 2014 was a year of relative balance in judicial voice, though some members of the Court were more visible than others. Justice Abella had just one joint majority opinion, and otherwise made her mark in dissenting and joint dissenting reasons. ${ }^{70}$ Already she has played a prominent role in 2015's Charter cases with a solo dissent in Meredith, the majority opinions in SFL and Loyola High School, and concurring reasons in Mouvement laïque québécois.

While Rothstein J. had two majority opinions, one dissent, and a partial joint dissent, Cromwell J. wrote four majority opinions, one concurrence, and one joint dissent. ${ }^{71}$ In 2015, Rothstein J. engaged actively on labour relations issues, and Cromwell J. co-wrote Gun Registry's majority opinion. Meantime, Moldaver J. had four majority opinions (including Hart and Mack, the Court's non-Charter Mr. Big cases), one concurrence, and a singular dissent in the Appointment Reference; in 2015 he wrote joint concurring opinions in Law Societies and Loyola, and a biting dissent in Nur. ${ }^{72}$

The Court's most senior puisne judge, LeBel J., who retired on November 30, 2014, wrote two majority opinions and teamed up with the Chief Justice in two of 2015's labour trilogy decisions. ${ }^{73}$ Justice Karakatsanis did not have a majority opinion in 2014, but wrote two concurrences and two dissents of significance, before co-authoring the

69 Mounted Police, supra, note 8 and Meredith, supra, note 48. For earlier joint opinions on labour relations issues by this team, see RWDSU, Local 558 v. Pepsi Cola Canada Beverages (West) Ltd., [2002] S.C.J. No. 7, [2002] 1 S.C.R. 156 (S.C.C.) (secondary picketing); Health Services and Support - Facilities Subsector Bargaining Assn. v. British Columbia, supra, note 10; and Ontario (Attorney General) v. Fraser, supra, note 50. Justices Rothstein and Abella were also active in this trio of cases, as they have been on these issues in the past. Justice Rothstein wrote a strong concurrence in Fraser, which read more like a dissent, and Abella J. dissented in the same case on the outcome. While Justice Rothstein wrote to minimize the constitutionalization of labour relations, Abella J., wrote in the opposite direction, to maximize the scope of s. 2(d).

70 The majority opinion was Bernard (joint opinion with Cromwell J.); the dissents were Babos and Kazemi Estate; and the joint dissent was Harkat (joint opinion).

71 Justice Rothstein's majority opinions were Mian and Conception (joint opinion with Cromwell J.); he dissented in Trial Lawyers and co-wrote a partial dissent with Moldaver J. in Bernard. Justice Cromwell's majority opinions were Spencer, Fearon, Bernard (with Abella J.), and Conception (with Rothstein J.); his concurrence was Trial Lawyers and his dissent was Harkat (with Abella J.). Justice Cromwell also wrote a concurring opinion in Hart.

72 The Moldaver J. majority opinions were Babos, Anderson, Mack and Hart; his concurrences, were MacDonald (Wagner J.), and Law Societies and Loyola High School (Chief Justice McLachlin).

73 Justice LeBel's majority opinions in 2014 were MacDonald and Kazemi Estate. 
majority opinion in the Gun Registry case in $2015 .^{74}$ Justice Wagner wrote twice, both times for a majority of the Court, and Gascon J.'s debut on the rights docket held that a prayer exercise in public municipal meetings violated Quebec's human rights legislation. ${ }^{75}$

To summarize, the survey reveals a functional balance between consensus and voice in decision writing at the McLachlin Court. Though the Chief Justice lauds it as a leadership priority, too much consensus is undesirable and can blunt the sharper edges of debate on difficult matters of constitutional policy. ${ }^{76}$ That said, and against a current of unanimity which was notable in the Aboriginal cases, the Senate Reference, and Carter - the jurisprudence produced significant dissents and valuable concurrences. That is reassuring, because it is through the engagement of argument and divergent points of view that the law's capacity for growth is best realized. Unanimity should not be overvalued at the expense of concurrences and dissents that, in most instances, enrich the jurisprudence and add to, rather than detract from, the Court's legitimacy. ${ }^{77}$

\section{LEGACY BUILDING}

By self-declaration Chief Justice McLachlin is not a legacy builder. For her, decision-making is not a matter of strategy or design, but instead describes a process of case-specific moments in which "conscious objectivity" joins fairness with human context to determine what justice

74 The concurrences were Hart and Conception; the dissents were Wakeling and Fearon. See S. Kari, "Carving out a Profile," Canadian Lawyer (April 2015), at 26-31 (discussing Karakatsanis J.'s decisions and their influence). For a comment on $R$. v. Conception in this volume, see S. Fraser, "Hospital Knows Best: Court and Unfit Accused at the Mercy of Hospital Administrators - The Case of R. v. Conception".

75 Justice Wagner's majority opinions were MacDonald (with Moldaver J.), and Wakeling; Justice Gascon's was Mouvement lä̈que québécois.

76 As noted above, the Chief Justice supports a process of decision-making that is aimed at eliminating "unnecessary voices" and "unnecessary concurrences"; supra, note 12. Further indication that consensus is at the core of her leadership is found in the following remarks, made in 2010: "[ $\mathrm{t}]$ he Court's work in the last ten years has been marked by a high degree of consensus. ... In the first year I was chief justice, consensus peaked at $82 \%$ - that is, in $82 \%$ of the cases were unanimous in the result. Unfortunately, the stats have been somewhat downhill from then on." (emphasis added) The Rt. Hon. Beverley McLachlin, P.C., "The First Decade of the 21st Century: The Supreme Court of Canada in Context", in D. Wright \& A. Dodek, eds., Public Law at the McLachlin Court: The First Decade (Toronto: Irwin Law Inc., 2011), Foreword.

77 See, e.g., W.D. Rankin \& M. Jamal, "Dissents and Concurrences: Seven Debates in Charter Jurisprudence" in B.L. Berger, J. Cameron \& S. Lawrence, eds., Constitutional Cases 2012, supra, note 11 , at 89. 
demands in any given setting. ${ }^{78}$ The jurisprudence that emerges is a fortuitous mix of whatever appeals are presented to the Court at any time; under this iteration, any legacy created in this way is incidental, and serendipitous.

2014 was nonetheless a legacy year for the McLachlin Court of political and legal or constitutional dimensions, which are interlocking but play distinctive roles in the narrative. To explain, deteriorating relations between the Court and federal leadership made 2014 a year of high profile and high stakes decision-making. The attack on the Chief Justice in spring 2014 was a purely political act and an attempt to politicize the Chief Justice, undermine her authority, and cast a dark shadow on the Court. Though relatively short-lived, the direct attack unquestionably placed the Court in crisis. Both before and after the crisis, the judges delivered a sharp and assertive series of decisions on constitutional law and Charter rights. Of interest in these dynamics is the interface between the political and legal, and - more to the point - the impact of politics on the law in a year of milestone decisions. The question, then, is whether the Court simply assumed a dutiful and unconcerned posture in decision-making much in the way the Chief Justice describes her own objectives - or, in the face of challenges to its authority and the authority of the law, chose instead to assert its institutional power and shape a legacy.

Surviving the political attack and consolidating its position in Canadian political life are central elements of the Court's legacy in 2014. When the Prime Minister and Minister of Justice picked a public fight with the Chief Justice, there was little she and her Court could do to respond publicly. Chief Justice McLachlin had no choice but to answer the serious allegations against her, but more generally the Court is powerless to defend itself from unfair accusations and commentary. ${ }^{79}$ Even so, the Court and Chief Justice emerged from the Nadon appointment crisis and its aftermath relatively unscathed. By most accounts, the challenge to her integrity was a foolish and impulsive gamble that did more to reinforce than damage the Chief Justice's reputation. It was widely seen as a base and unsophisticated move to

78 As she explained, judgment is "not a coldly neutral evaluation of competing positions, robotically free of compassion or perspective" but "an engaged, human act of imagination". Under this approach the judge will put herself "in the shoes of the different parties, and think about what it looks like from their perspective, and really think about it, not just give it lip service". Brean, "Conscious Objectivity", supra, note 12.

79 S. Fine, "Chief Justice hits back at prime minister over claim of improper call", The Globe and Mail (May 2, 2014), online: <http://www.theglobeandmail.com/news/politics/chiefjustice-denies-allegations-of-improper-contact-with-pmo/article18397514/>. 
undermine the Supreme Court - understood by the government as an adversary - by attacking Chief Justice McLachlin personally. The allegations were thought transparently without merit, and the campaign not only backfired but arguably strengthened and consolidated the legitimacy of the Court and Chief Justice. ${ }^{80}$

Attention on the Court was constant in this period. Whether the judges might deal the government further setbacks and how the government might respond to a feisty Court were ongoing themes in a news environment that feasted on the prospect of ongoing institutional conflict. Headlines with a thirst for controversy spoke of the Court as "the government's nemesis", named the Chief Justice as the true "leader of the opposition", described the government's "potshots" at the Court, and dwelled on the "political firestorm" and "cold legal war". 81 Throughout, it was not the manner of this discourse to defuse, but instead to heighten and highlight the sense of a contest between the Court and the political leadership. ${ }^{82}$ In this process the Court and Chief Justice

$80 \quad$ See generally J. Ivison, "Tories incensed with Supreme Court as some allege Chief Justice lobbied against Marc Nadon appointment", National Post (May 1, 2014), online: $<$ http://news.nationalpost.com/news/canada/canadian-politics/tories-incensed-with-supreme-court-assome-allege-chief-justice-lobbied-against-marc-nadon-appointment>; C. Blatchford, "Chief Justice could have avoided catfight with PMO by recusing herself from Nadon ruling", National Post (May 2, 2014), online: <http://news.nationalpost.com/full-comment/chief-justice-could-have-avoided-catfightwith-pmo-by-recusing-herself-from-nadon-ruling>; and A. Wherry, "Stephen Harper, Beverley McLachlin and an historic mess", Maclean's (May 6, 2014), online: <http://www.macleans.ca/ politics/stephenharper-beverley-mclachlin-and-historic-mess/>.

It is baffling that the Prime Minister and Minister of Justice would have acted on such a risky and unfounded course of action. On other occasions in the past, political leaders have discovered the folly of challenging Supreme Court powers and learned that doing so is a low percentage strategy. It is just as surprising that the lesson has not been internalized, and government Ministers continue to voice disrespect for the Court's decisions. On June 11, 2015, Health Minister Ambrose responded to the Supreme Court's decision on medical marijuana by stating, "Frankly, I'm outraged by the Supreme Court of Canada". "Medical marijuana legal in all forms, Supreme Court rules", CBC News online (June 11, 2015): <http://www.cbc.ca/news/politics/medical-marijuana-legal-in-all-forms-supremecourt-rules-1.3109148>. See Smith, supra, note 9.

${ }_{81}$ J. Brean, "Unofficial Leader of the Opposition", National Post (May 23, 2015) at A9; C. Schmitz, "Chief Justice taking long view after year of political firestorms", The Lawyers Weekly (March 6, 2015).

C. Black, "Canada's judicial oligarchy", National Post (May 30, 2015) at A16; and L. Gagnon, "McLachlin's comments a disservice to her court, and to aboriginals", The Globe and Mail (June 10, 2015), online: <http://www.theglobeandmail.com/globe-debate/mclachlins-comments-a-disserviceto-her-court-and-to-aboriginals/article24879482/>.

82 The commentary runs a tally of government policies the Court has rejected or invalidated and promotes the perception of combat between the institutions. See, e.g., T. Hopper, "A scorecard of Harper government's wins and losses at the Supreme Court of Canada", National Post (April 15, 2015), online: <http://news.nationalpost.com/news/canada/scoc-harper-gov-scorecard-741324>; and S. Fine \& C. Hannay, "Harper v. the Supreme Court: Five recent losses for the PM", The Globe and 
absorbed some heat, in the form of renewed complaints about Canada's "judicial oligarchy", and dissent from the "ever-rising hallelujah chorus of adulation being orchestrated by and for the chief justice". ${ }^{83}$ This spring McLachlin C.J.C. was chastised for naming Canada's treatment of Aboriginals "cultural genocide". 84 The Court unquestionably has detractors and critics who can and should question the exercise of its powers, especially in light of the recent jurisprudence. Still, there has as yet been no groundswell of opposition to the Court. Instead, the appetitewhetting "dialogue" — or shouting match, as some might say between institutions and institutional leaders has served immeasurably to raise the profile of the Court and its Chief Justice. ${ }^{85}$

The furor surrounding Supreme Court appointments, the attack on the Chief Justice, and the climate of institutional hostility also has an inside story. Though this story is closely held between members of the Court, there can be no doubt that the roiling events around Supreme Court appointments had an impact on the Chief Justice and the judges. From one perspective, the quantitative survey can support a conclusion that these dynamics did little to ruffle the Court because the annual numbers and results are in line with the general pattern of recent years. But as shown here, the Court produced a legacy-setting jurisprudence in this period - before and after the appointment controversy — which features constitutional and Charter milestones. To be sure, there is a sense of the federal government driving the agenda, not only by stating reference questions the Court was required to

Mail (April 25, 2015), online: <http://www.theglobeandmail.com/news/politics/harper-v-the-supremecourt-five-recent-losses-for-the-pm/article18206422/?page=all $>$. On the Appointment Reference, see A. Dodek, "Nadon decision is Supreme Court's declaration of independence", The Globe and Mail (March 21, 2014), online: <http://www.theglobeandmail.com/globe-debate/nadon-decision-issupreme-courts-declaration-of-independence/article17611438/>; and E. Macfarlane, "The Supreme Court's remarkable rejection of Marc Nadon", Maclean's (March 21, 2014), online: <http://www. macleans.ca/politics/the-supreme-courts-remarkable-rejection-of-marc-nadon/>. On Senate reform see M. Friedman, "The Senate Reference Decision Reeks of Legal Elitism”, Huffington Post (May 1, 2014), online: <http://www.huffingtonpost.ca/mark-friedman/senate-reference_b_5243129.html>; and E. Macfarlane, “Did the Supreme Court just kill Senate reform?”, Maclean's (April 25, 2014), online: <http://www.macleans.ca/politics/did-the-supreme-court-just-kill-senate-reform/>.

83 C. Black, "Canada's judicial oligarchy," supra, note 81, at A16. See also Charles McVety of the Institute for Canadian Values, commenting as follows on the Carter decision: "Shame on Chief Justice Beverley McLaughlin [sic] and her decade-long campaign teaching judges to be 'policy law makers' ... . Now unelected, appointed individuals are acting as philosopher kings ruling over our country. This is not democracy." Quoted in J. Ivison, "The public backs court on decision", The Globe and Mail (February 7, 2015) at A2.

${ }_{84}$ See, e.g., L. Gagnon, supra, note 81 , at A16.

85 K. Roach, The Supreme Court on Trial: Judicial Activism or Democratic Dialogue (Toronto: Irwin Law, 2001) (describing institutional relations between the Court and the legislatures, at least at times, as a "shouting match"). 
answer but, as well, by pressing criminal justice policies in the undoubted knowledge that at least some would run afoul of the Charter. Those dynamics do not tell all because decisions such as Tsilhqot'in Nation, Trial Lawyers, SFL, and the religious freedom cases involved challenges to legislation and actions at the provincial level. Nor can serendipity explain this year's legacy jurisprudence: apart from references and appeals as of right the Court chooses its agenda. In any event, it is not only what the Court decides but, more to the point, how it decides cases that identifies and defines the core of the jurisprudence.

The Supreme Court's jurisprudence in this period is not the work of an institution that was unnerved by the federal government's hostility toward the Court and its mandate of review. In the face of danger the Chief Justice and the Court coalesced and stepped up to the challenge. What stands out are the References, both of which provided negative answers to questions seeking institutional permission to proceed with constitutionally doubtful plans but, in doing so, addressed the interpretive or structural framework for constitutional amendments affecting national institutions; Tsilhqot'in and Trial Lawyers, both of which broke new ground in constitutional interpretation; and 2015 Charter decisions which formally and informally overruled long-standing precedent to move rights protection in new directions on labour relations and assisted suicide, before resetting the section 12 jurisprudence to place restrictions on the government's sentencing policies. There is a sense of mission in these decisions and perhaps even of a carpe diem moment for the Court. With the Court's composition set to change with the retirements of LeBel J. and Rothstein J., a spurned Prime Minister determined to close the appointment process to public view and limit accountability for his choices, and the telling incidence of dissent in some of the 2015 Charter cases, the Court majority might have considered it serendipitous - if not strategically opportune - to reconsider the constitutional rules and reset the Charter by overruling precedent and embedding new authority in the jurisprudence. Looking ahead, the cautionary note in reflecting on this "legacy jurisprudence" is that most decisions in this period were not decided by a full Court and that the configuration on key issues may well change as recent appointees take their place in the complement. ${ }^{86}$

${ }^{86}$ On July 27, 2015, the Prime Minister announced the appointment of Justice Russell Brown to the Supreme Court of Canada; Justice Brown replaced Rothstein J., online: <http://pm.gc.ca/eng/ news/2015/07/27/pm-announces-appointment-supreme-court-canada $>$. 
The Chief Justice's role throughout is intriguing and warrants deeper reflection. On the political front, she managed the difficult circumstances of the Appointment Reference and attack on her integrity skilfully, incurring little reputational damage in personal or institutional terms. She was able to lead the Court through challenging moments and yet still generate a jurisprudence that has set new principles in the constitutional bedrock. These accomplishments are beyond what pure serendipity can deliver. As discussed, the Chief Justice prioritizes consensus and collaboration though, by virtue of her position and institutional history, has enormous authority within the Court. ${ }^{87}$ She eschews thoughts of a legacy but has flagged Aboriginal peoples, labour relations, access to justice, and matters of conscience (i.e., as in Rodgriguez and Carter) as issues of personal concern; it is evident she also cares deeply about and is willing to defend the rule of law and integrity of national institutions. It hardly seems a coincidence, then, that the Court's jurisprudence produced major shifts in each of these areas, and that the Chief Justice played an important role in several as author of the Court's opinion. ${ }^{88}$ Recalling her comment in 2010, that most Charter interpretations had already been made, one of the ways to build a legacy - when precedent presents an obstacle - is to sweep it away, as was done expressly in the labour relations cases and by judicial sleight of hand in Bedford as well as in Carter. Whether and how the law and its evolution remain orderly, in such circumstances, raises important issues.

What should not be open to question is the Chief Justice's legacy in 2014. Despite her reluctance, the Chief Justice should have a legacy, and already does. That legacy extends over her tenure as Chief Justice and her many years at the Court as a puisne judge. It is a rich legacy that by now includes more than 400 opinions on all manner of issues, and admirable leadership of the Court. Even so, it is predictable that 2014 will always stand out from her other years on the Court. It was a singular and even historic year that was overshadowed by negative and troubling institutional dynamics. But more to the point of this review, 2014 was also a singular year of legacy building for the Chief Justice and her Court.

\footnotetext{
${ }^{87}$ In early 2015 , five of the Court's judges - more than half — had been sitting less than four years. Justice Abella is the senior puisne judge, and the Chief Justice had already been on the Court for 15 years when Abella J. was appointed in 2004.

88 She wrote in Tsilhqot'in Nation, Trial Lawyers and Mounted Police; it is otherwise unknown what role she might have played in the Court's anonymous reasons in the References and in Carter.
} 